University of Montana

ScholarWorks at University of Montana

Graduate Student Theses, Dissertations, \&

Professional Papers

1983

\title{
Light reduction and moisture stress effects on growth and water relations of western larch seedlings
}

Nan C. Vance

The University of Montana

Follow this and additional works at: https://scholarworks.umt.edu/etd

Let us know how access to this document benefits you.

\section{Recommended Citation}

Vance, Nan C., "Light reduction and moisture stress effects on growth and water relations of western larch seedlings" (1983). Graduate Student Theses, Dissertations, \& Professional Papers. 2844.

https://scholarworks.umt.edu/etd/2844

This Thesis is brought to you for free and open access by the Graduate School at ScholarWorks at University of Montana. It has been accepted for inclusion in Graduate Student Theses, Dissertations, \& Professional Papers by an authorized administrator of ScholarWorks at University of Montana. For more information, please contact

scholarworks@mso.umt.edu. 


\section{COPYRIGHT ACT OF 1976}

THIS IS AN UNPUBLISHED MANUSCRIPT IN WHICH COPYRIGHT SUBSISTS. ANY FURTHER REPRINTING OF ITS CONTENTS MUST BE APPROVED BY THE AUTHOR.

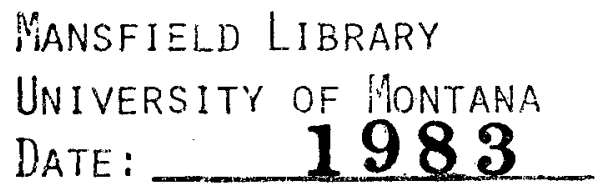





\title{
LIGHT REDUCTION AND MOISTURE STRESS EFFECTS \\ ON GROWTH AND WATER RELATIONS \\ OF WESTERN LARCH SEEDLINGS
}

\author{
By \\ NAN C. VANCE \\ B.A., University of Maryland, 1970
}
Presented in partial fulfillment of the requirements for the degree of Master of Science UNI VERSITY OF MONTANA
1983

Approved by:

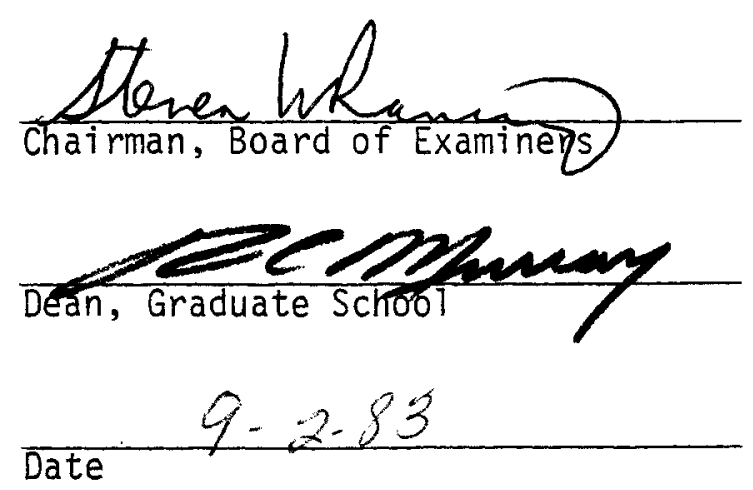


UMI Number: EP33836

All rights reserved

INFORMATION TO ALL USERS

The quality of this reproduction is dependent on the quality of the copy submitted.

In the unlikely event that the author did not send a complete manuscript and there are missing pages, these will be noted. Also, if material had to be removed, a note will indicate the deletion.

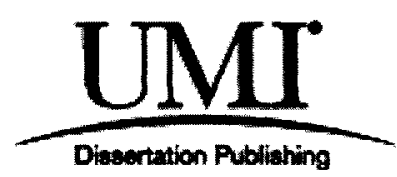

UMI EP33836

Copyright 2012 by ProQuest LLC.

All rights reserved. This edition of the work is protected against unauthorized copying under Title 17, United States Code.

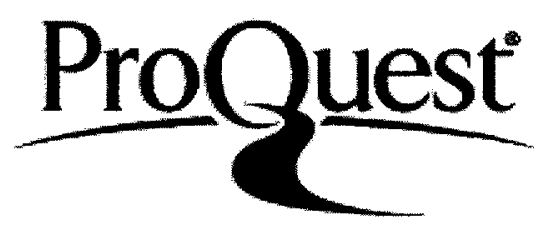

ProQuest LLC.

789 East Eisenhower Parkway

P.O. Box 1346

Ann Arbor, Ml 48106 - 1346 
Vance, Nan C., M.S., July 1983

Forestry

Light reduction and moisture stress effects on growth and water relations of western larch seedlings ( $32 \mathrm{pp}$. )

Director: Dr. Steven W. Rpnning

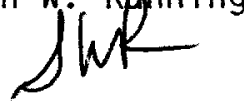

Ten week old western larch (Larix occidentalis Nutt.) seedlings were grown in a greenhouse under 70,37 , and $27 \%$ full sunlight from late July to early October. In August seedlings under each light treatment were stress cycled until predawn seedling water potential $\left(B \Psi_{p}\right)$ reached one of 3 levels: no stress ( $>-0.4 \mathrm{MPa}$ ), moderate stress $(-0.7$ to $-1.0 \mathrm{MPa})$ and severe stress $(-1.5$ to $-1.8 \mathrm{MPa})$. Seedlings were sampled for height, diameter, shoot and root dry weights and analyzed by ANOVA. Shoot/root ratios were calculated and time of terminal bud set noted. Diurnal leaf conductance $\left(K_{1}\right)$ and seedling water potential $\left(\Psi_{p}\right)$ were measured and water relations compared to those of other species.

Moisture stressing significantly reduced height and diameter of seedlings grown under $70 \%$ 1ight. Light reduction reduced biomass accumulation in shoot and root. A positive linear relation was found between root dry weight and light intensity. The largest seedlings (on a weight basis) received the highest light, were unstressed and had the lowest shoot/root ratios. Terminal bud set was not affected by light reduction or moisture stressing but occurred under a 14 hour photoperiod and reduced nighttime temperatures. Stressed and shaded seedlings had significantly reduced diurnal $K_{l}$ and stress cycled seedlings showed an adjustment to stressing. The $K_{1}$ of unstressed seedlings was correlated with humidity deficit (ABHD), of stressed seedlings, with $B \Psi_{p}$ and $A B H D$. Maximum $K_{1}$ declined with decreasing $B \Psi_{p}$ but not to a level indicating complete stomatal closure. 


\section{ACKNOWLEDGEMENTS}

I want to thank Dr. Steven Running for his professional help and thoughtful suggestions, and for providing me with the opportunity and means for carrying out this research.

And special thanks to Judy Revere whose expertise in thes is preparation and invaluable support down to the finish line helped me bring this thesis about.

I also want to gratefully acknowledge the Montana State Department of Lands, Division of Forestry, Will is Heron and Steve Bodmer for their generous donation of facilities, and cooperation in conducting the research. 
TABLE OF CONTENTS

ABSTRACT. ......................... $i$.

ACKNOWLEDGEMENTS. .................... $i$...

LIST OF TABLES. . . . . . . . . . . . v v

LIST OF FIGURES ................... vi

INTRODUCTION. . . . . . . . . . . . . . . 1

MATERIALS AND METHODS ................ 2

RESULTS AND DISCUSSION. ............ 5

Growth and Morphology........... 5

Dormancy Induction ............ 15

Water Relations. ............ 16

CONCLUSIONS . . . . . . . . . . . . . . . . . 28

LITERATURE CITED. . . . . . . . . . . 30 


\section{LIST OF TABLES}

Table 1. Analys is of differences in morphology and dry matter accumulation and

distribution. . . . . . . . . . . .

Table 2. Summary of regressions of leaf conductance with humidity deficit, predawn xylem water potential, and both independent variables entered stepwise. . . . . . . . . . 


\section{LIST OF FIGURES}

Figure 1. Change in height of unstressed (O), moderately (O), and severely (O) stressed seedlings under $70 \%$ light over the 20 week study. (Each point is the mean of 15 measurements.) Height difference of moisture stressed seedlings under $37 \%$ and $27 \%$ light was not detected therefore data not shown. . . 8

Figure 2. Change in diameter of unstressed western larch seed 7 ings under $70 \%(\boldsymbol{O}), 37 \%(\boldsymbol{\Delta})$, and $27 \%$ (a) full 1 ight over. the 20 week study, also, change in diameter of severely stressed $(O)$ seedlings under $70 \% 1 \mathrm{ight}$. Each point is the mean of 15 measurements. Differences in diameter under other moisture stress treatments not detected therefore, data not shown......... 10

Figure 3. Change in root dry weight of unstressed western larch seedlings under 70\% (O), $37 \%(\boldsymbol{\Delta})$, and $27 \%$ ( $)$ ) 1 ight treatments over the 20 week study. Each point is the mean of 15 measurements. ..........

Figure 4. Diurnal measurements taken August 4, 1982 of photon flux density (PPFD), absolute humidity deficit (ABHD) and leaf conductance $\left(K_{1}\right)$ of unstressed $\left(B \Psi_{p}=12.5-20.0 \mathrm{MPa}\right)$. Stressed and unstressed seedlings denoted by $(O)$ and (O) respectively. All points are means of 3 seedlings with one standard error indicated (bars)................

Figure 5. Diurnal measurements taken August 16, 1982 of absolute humidity deficit (ABHD), seedling water potential $\left(\Psi_{p}\right)$, and leaf conductance $\left(K_{1}\right)$ of unshaded (0), shaded ( $\boldsymbol{\square})$, and stressed (O) seedlings. All points are means of 3 seeldings with one standard error indicated (bars) 


\section{List of Figures (continued)}

Figure 6. A second degree regression from a least squares curve fit of maximum morning leaf conductance $\left(K_{1}\right)$ on predawn seedling water potential $\left(B \Psi_{n}\right)$. The solid line is from the equation fitting the data points for western larch. The dashed line is for lodgepole pine from Running (1980). . . . . . 24

Figure 7. Seedling predawn $x y l$ em pressure potential (Bษp) during two consecutive stress cycles. Each point is the mean of 3 measurements taken of seedlings under $70 \%(O)$ and $27 \%$ ( $\square)$ light treatments. The first stress cycle is denoted by ( - ) , the second cycle by (-.)............... 26 


\section{INTRODUCTION}

Western larch (Larix occidentalis Nutt.) is valued as a commercial species (Owens and Molder 1979, Schmidt et al. 1976), al though its range is restricted to the interior northwestern United States and southern portions of western Canada. Highly intolerant, this pioneer species grows best under full sunlight of clearcuts (Schmidt et al. 1976). Yet drought, named as one of the most important causes of seedling mortality in western larch, reduces the survival rates of out planted seedlings.

A major goal in rearing conifer seedlings is to produce seedlings morphologically and physiologically suited for withstanding the rigors of planting and the site (Cleary et al. 1978, Tinus and McDonald 1979). Meeting that objective is difficult with western larch, an atypical deciduous conifer species which is usually reared under growing regimes adjusted by trial and error. Nursery personnel regularly moisture stress western larch seedlings to stop height growth and induce dormancy without knowing the effects of plant water stress on the seedlings since this species has received little formal physiological study. Yet the increased use of nursery and greenhouse grown western larch seedlings for reforestation emphasizes the need for basic physiological, morphological and growth data.

The effects of manipulating the greenhouse environment on seedling morphology and physiology should be determined before deciding on the characteristics that can be correlated with survival. Since changes 
in the moisture and light environment strongly affect seedling growth and physiology (Kozlowski 1971, Levitt 1972, Larson 1974), the objective of this study is to examine moisture stressing and light intensity reduction effects on height, diameter, dry matter accumulation and distribution, and timing of bud set. The study also will examine the effects of moisture stressing and light reduction on seedling water potential and leaf conductance.

\section{MATERIALS AND METHODS}

Western larch seed were obtained from Montana Department of State Lands, Forestry Division. Seed were randomly selected from seed lot 776-SDF, collected Fâ1l 1980 from Big Creek, Mt. at about $1200 \mathrm{~m}$ elevation and $48^{\circ} 35^{\prime}$ latitude, and cold stored. Seed were stratified for 23 days, sown in Ray Leach tübes (\#4) and grown in the Montana State Nursery greenhouse, Missoula, Montana during the Spring and Summer of 1982. Seedlings were grown in a peat-vermiculite medium (Grace Products) and under controlled environmental conditions of an operational greenhouse: $30 / 20^{\circ} \mathrm{C}$ temperatures, 50 to $80 \% \mathrm{RH}$, with a 24 hour photoperiod by supplemental lighting. Seedlings were watered by an overhead sprinkling system and fertilized with a commercial fertilizer which included micronutrients (Peters, 9-45-15 and 20-20-20). At the end of July when the seedlings were about 10 weeks old, a set of 15 randomly sampled seedlings were harvested and baseline measurements of height; stem diameter, measured just above the root collar; 
shoot and root oven dry weight $\left(70^{\circ} \mathrm{C}\right.$ for $\left.48 \mathrm{hr}\right)$ were determined. Supplemental photoperiod lighting was discontinued and treatments began.

Light readings taken with a quantum sensor (LI-COR 190S) and averaged during peak photosynthesizing hours indicated that on the average photosynthetic photon flux density at peak irradiance was about $1400 \mu \mathrm{E} \mathrm{m}^{-2} \mathrm{~s}^{-1}$ having been reduced $30 \%$ through the greenhouse glazing. Two 1 ight reduction treatments were applied by using commercial shade cloths. Each shade shelter covered 600 seedlings ( 3 container trays) and another 600 were left uncovered for the highest of the three light treatments. The uncovered and the two shade treatments provided a growing environment under $70 \%, 37 \%$ and $27 \%$ full irradiance.

After all seedlings were watered to saturation, a subset of 200 seedlings from each light treatment were given one of three moisture stress treatments. One set was watered at a frequency to prevent significant moisture stress or predawn seedling water potential $\left(B \Psi_{p}\right)$ above $-0.4 \mathrm{MPa}$. Water was withheld from another set until $B \Psi_{p}$ reached -0.7 to $-1.2 \mathrm{MPa}$ (moderate stress), and from a third set until $\mathrm{B \Psi}$ reached -1.5 to $-1.8 \mathrm{MPa}$ (severe stress). Stress development was monitored by measuring $B \Psi_{p}$ with a pressure chamber on sampled seedlings clipped above the root collar (Ritchie and Hinckley 1975). The stress treatments involved two consecutive moisture stress cycles, each taking from 1 to about 2 weeks to complete. During the moisture stress cycling fertilizer was withheld so as not to confound effects of the stress 
treatments. Morphological changes and date of bud set were noted. At the end of the period (August 16) 15 seedlings randomiy sampled from each light and moisture stress treatment (135 seedlings) were harvested and height, diameter, shoot and root dry weight were measured.

Following the moisture stress cycling, seedlings were fertilized week1y with 5-11-26 (Peters). In August the greenhouse temperatures were lowered to $25 / 13^{\circ} \mathrm{C}$ to prepare seedlings for dormancy and cold hardening. Seedlings were moved outside by the end of September to continue cold hardiness development under short days and cool nights and final data were taken the first week in October. Shoot dry weight was not measured because of extensive needle drop. Data results were treated by analysis of variance. Significant differences in treatment effects were determined by Duncan's multiple range test.

Diurnal moisture stress development in shaded and unshaded seedlings from the unstressed treatments was measured August 16 at approximately 2 hour intervals with the pressure chamber. Measurements of water potential $\left(\Psi_{p}\right)$ were taken of the entire seedling shoot clipped above the root collar.

Leaf conductance $\left(k_{1}\right)$ was measured August 4 during the first stress cycle and August 16 during the second stress cycle on intact seedlings with a null balance diffusion porometer (Beardsell et al. 1972). Approximately 3 to $4 \mathrm{~cm}$ of the seedling terminal gernally having about 30 to 50 needles, or about $20-30 \mathrm{~cm}^{2}$ of total needle surface area, were enclosed in the cuvette. Photosynthetic photon flux density (PPFD) 
was measured with a quantum sensor (LI-COR 190S), temperature with a platinum thermistor and relative humidity with a Vaisala sensor at the same time conductance measurements were taken. The following morning before sunrise each seedling was clipped and $\left(B \Psi_{p}\right)$ was measured. Because the method of measuring $B \Psi_{p}$ was destructive, sample sizes were 3 for each data point unless otherwise stated. Al1 measurements were taken on sunny days.

Leaf area used in the conductance determinations were calculated with a LI-COR portable surface area meter. The planar surface area was corrected to total surface area under a slightly modified method described by Drew and Running (1975). A scanning electron microscope was used on prepared needles (dehydrated in a graded series of ethanol solutions, critical-point dried, and coated with gold) and polaroid photographs obtained. Direct measurements were made on 10 random needle samples to calculate the ratio of leaf curvature to the width of the planar surface. The correction factor for needle curvature used to calculate total surface area was determined to be 2.23 .

\section{RESULTS AND DISCUSSION}

Growth and Morphology

Mean heights of seedlings harvested October 5, 1982 are presented in Table 1. The effects of light reduction on height growth were not statistically significant at the .05 level of confidence. The mean 
Table 1. Analys is of differences in morphology and dry matter accumulation and distribution.

HEIGHT

$70 \% \begin{gathered}\text { LIGHT TREATMENT } \\ 37 \%\end{gathered} \quad 27 \%$

centimeters

August 16

1.

2.

3.

13.56

12.80

12.41

12.77

12.65

12.54

12.51

12.53

October 5

1 .

\begin{tabular}{lll}
15.77 & 15.05 & 14.89 \\
\hline 12.67 & 13.77 & 13.78
\end{tabular}

2.

12.67

13.77

13.19

14.07

13.78

.

DIAMETER

centimeters

August 16

1.

2.

3.

October 5

1.

2.

3.

\begin{tabular}{lll}
.197 & .180 & .173 \\
.173 & .178 & .168 \\
\hline .187 & .161 & .149 \\
\hline .251 & .206 & .196 \\
.238 & .205 & .194 \\
.228 & .196 \\
\hline
\end{tabular}

SHOOT DRY WEIGHT

grams

August 16

1.

2.

3.

\begin{tabular}{lll}
.405 & .345 & .352 \\
\hline .357 & .354 & .327 \\
\hline .387 & .322 & .297 \\
\hline
\end{tabular}

ROOT DRY WEIGHT

grams

August 16

1.

.237

.203

2.

.209

October 5

3.

.559

.537

.509

\begin{tabular}{ll}
.182 & .171 \\
\hline .162 & .132 \\
\hline .167 & .139 \\
\hline .355 & .285 \\
.343 & .267 \\
.343 & .241
\end{tabular}

SHOOT/ROOT RATIO

August 16

1.

2 .

\begin{tabular}{lll}
1.74 & 2.02 & 2.14 \\
\hline 1.76 & $\frac{2.31}{2.04}$ & 2.53 \\
1.86 & 2.16 \\
\hline
\end{tabular}

Numbers $1,2,3$ denote no, moderate and severe moisture stress treatments respectively. Nonsignificant differences for group means at the .05 level by Duncan multiple range test. Nonsignificant differences connected by solid line. 
height $(14.89 \mathrm{~cm})$ of seedlings grown under $27 \%$ light was about 1 centimeter less than the mean height $(15.77 \mathrm{~cm})$ of seedlings grown under $70 \%$ light, but the variability within treatment population heights made detecting significant differences impossible. Rehfeldt (1982) also found height variability within populations and attributed it to the exogenous nature of western 1 arch shoot growth.

Despite the variability, statistically significant differences in height were detected as a result of moisture stressing (Figure 1). Moisture stressing effects were significant under $70 \% 1$ ight only, however.

Although bud formation was visible before August 16, curiously, there was significant height growth (about $2 \mathrm{~cm}$ ) of the unstressed seedlings between August 16 and October 5 . This may have been due to the continual growth or "free growth" habit of western larch (Rehfeldt 1982, Owens and Molder 1979) and to the late seasonal growth pattern which is characteristic of Lamix (Tranquillini 1979, Ledig and Botkin 1974, Kozlowski 1971). Growth after August 16 of the moisture stressed seedlings was less than the unstressed seedlings which also suggests that growth after the appearance of the terminal bud did indeed occur, since one of the first responses to moisture stress by a growing plant is inhibition of cell enlargement (Hsiao et al. 1976).

Light reduction treatments significantly decreased mean diameter of seedlings harvested August 16 and October 5 (Table 1). Moisture stress did not affect diameter except for the severely stressed seedlings grown under $70 \%$ light which were significantly smaller in diameter (Figure 2). 
Figure 1. Change in height of unstressed $(0)$, moderately $(0)$, and severely $(O)$ stressed seedlings under $70 \%$ light over the 20 week study. (Each point is the mean of 15 measurements.) Height difference of moisture stressed seedlings under $37 \%$ and $27 \%$ light was not detected therefore data not shown. 


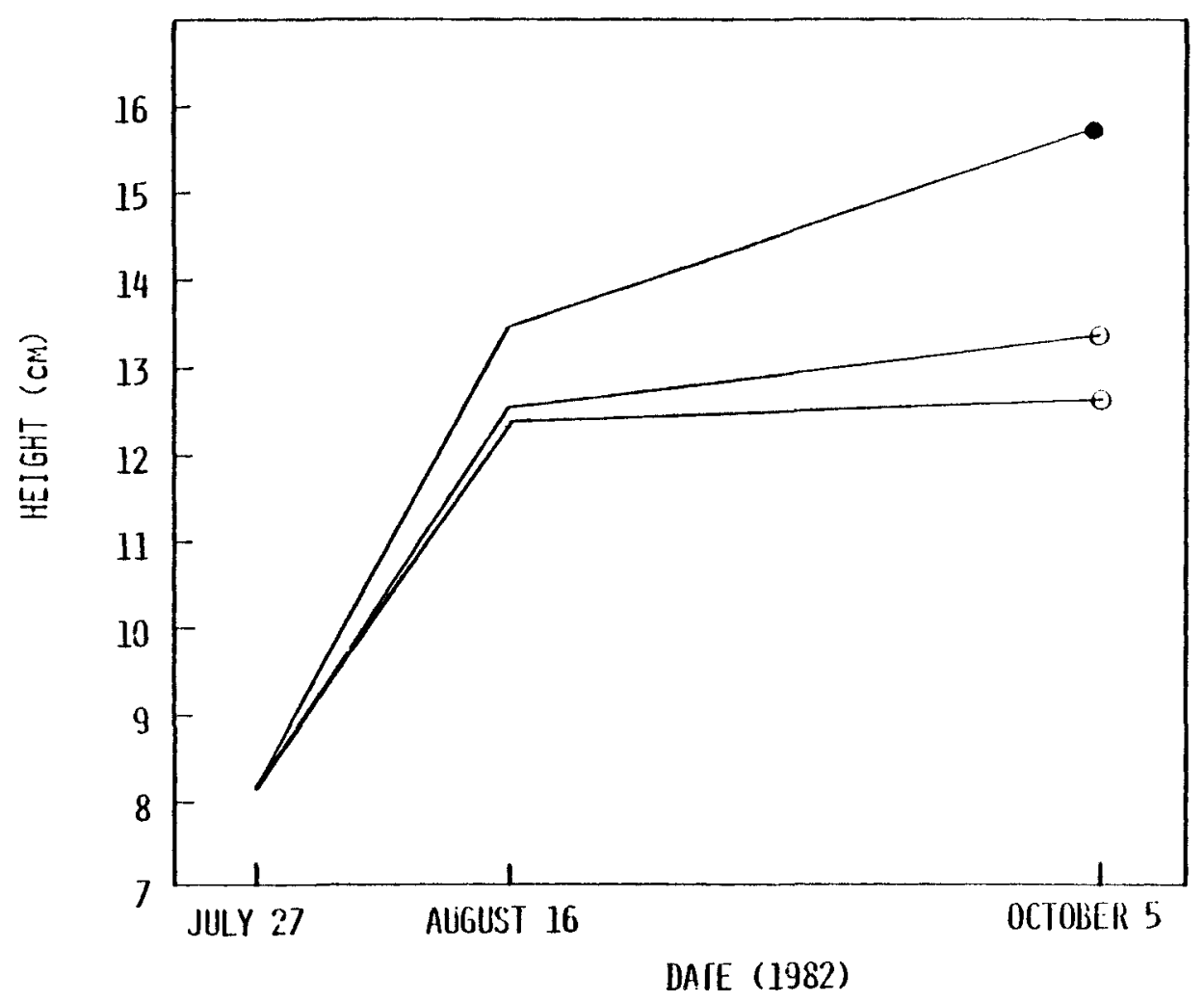


Figure 2. Change in diameter of unstressed western larch seedlings under $70 \%$ (O), 37\% (A), and $27 \%$ ( $\mathbf{A}$ ) full light over the 20 week study, also, change in diameter of severely stressed $(O)$ seedlings under $70 \%$ light. Each point is the mean of 15 measurements. Differences in diameter under other moisture stress treatments -not detected therefore, data not shown. 


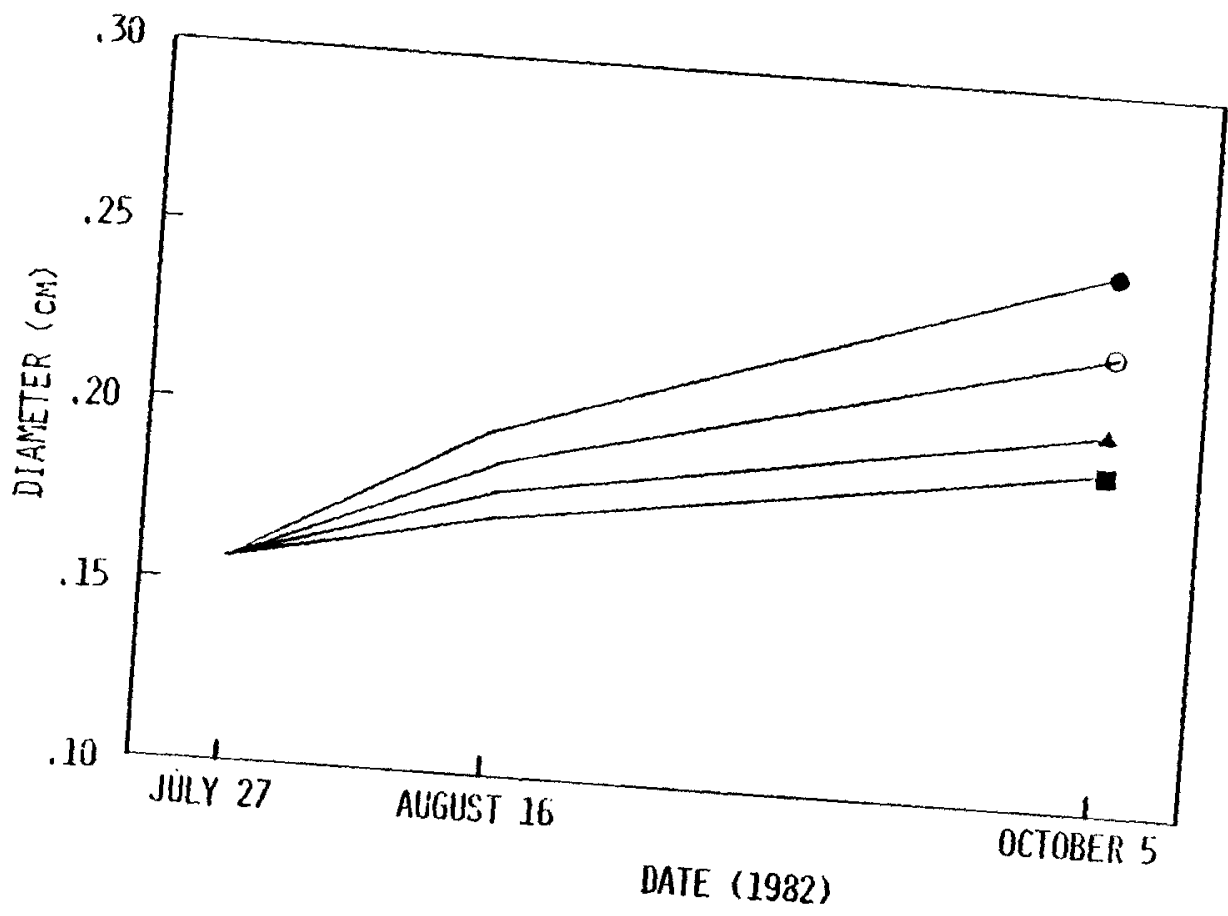


A fungus, Botrytis cinerea, infected seedlings in September causing considerable needle drop, so shoot dry weights were not calculated in October. Shoot dry weights were determined on seedlings harvested August 16. Analysis showed a significant difference in dry weight between the means of the severely stressed seedlings under the $70 \%$ and the 1 ight reduction treatments (Table 1).

There was a significant effect of light reduction treatments on root dry weight (Table 1). The increase in allocation of dry matter to roots by October was greatest in seedlings grown under $70 \%$ iight (Figure 3) and agreed with Shiroya et al. (1962) who found more photosynthate was transferred to the roots by pine seedlings grown under higher light intensity. A regression analysis of root dry weight with percent light showed a significant positive linear association $\left(r^{2}=.68\right)$. This positive association to light intensity of tolerant as well as intolerant conifer seedlings has also been found by Fairbairn and Neustein (1970) and Logan (1966).

The translocation of photosynthate to the roots between August and October related to seasonal changes in carbon distribution and the ability of the seedlings to continue positive carbon uptake into late Summer and early Autumn (Figure 3). Ledig and Botkin (1974) showed stem and root dry weight in European larch (Larix decidua Mi11.) and Japanese 1arch (Larix ZeptoZepis(Sieb. \& Zucc.) Gord.) increased 5-6 fold between August and October. The high dry weight increase was attributed in part to their relatively high photosynthetic rate in late summer. This data suggest that western larch maintained positive $\mathrm{CO}_{2}$ uptake late in the growing season as well. 
Figure 3. Change in root dry weight of unstressed western larch seed 1 ings under $70 \%(\mathbf{O}), 37 \%(\boldsymbol{\Delta})$, and $27 \%$ ( $)$ light treatments over the 20 week study. Each point is the mean of 15 measurements. 


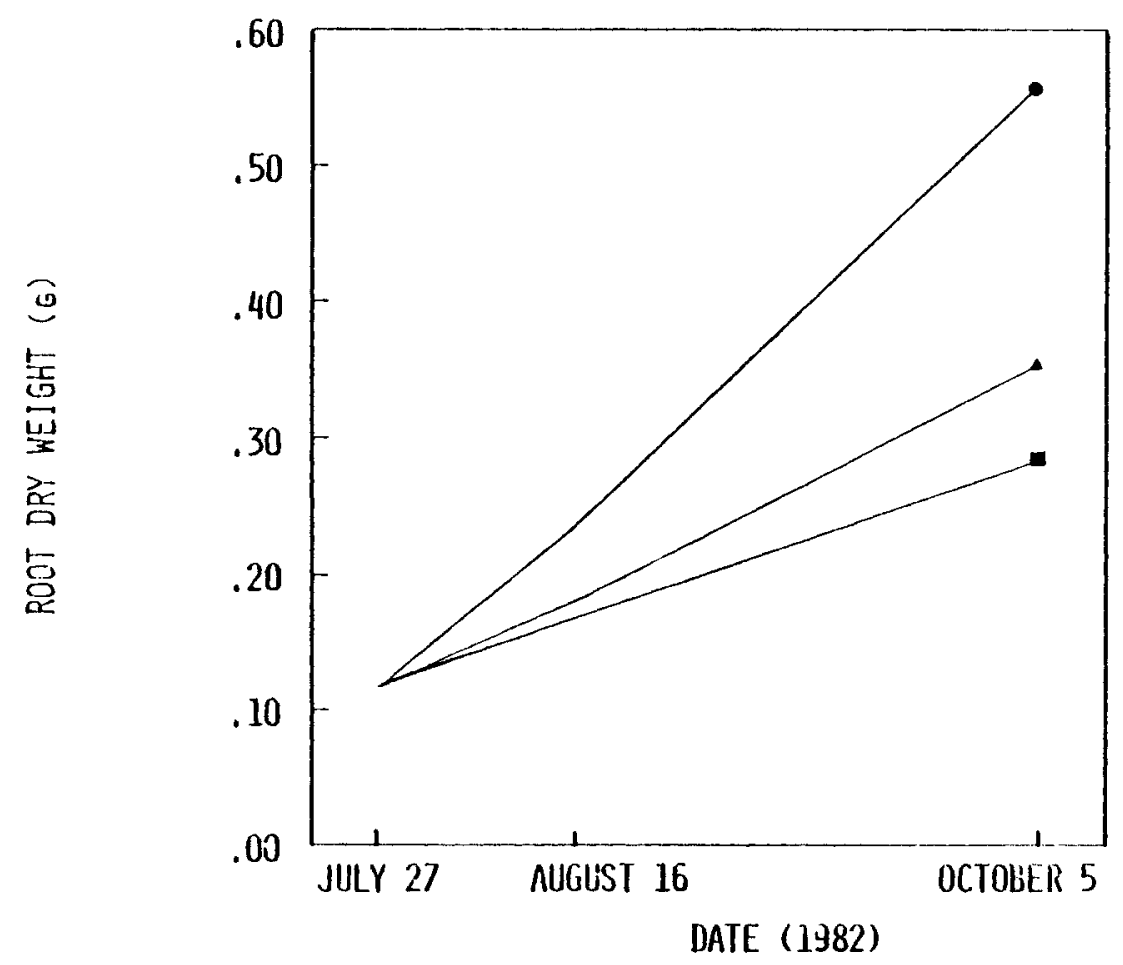

占 
Shoot/root ratios were calculated from seedlings harvested August 16 and results are shown in Table 1. Across two moisture stress treatments, there was a significant reduction in the shoot/root ratio of seedlings grown under $27 \%$ light; however, there was no difference due to moisture stressing. Reduction of light intensity apparently affected allocation of photosynthate to the roots more than to the shoots. How light reduction affects shoot/root ratios of conifer seedlings has been rigorously analyzed (Ledig et al. 1970, Ledig and Perry 1965). Ledig et a1. (1970) cautioned that while analysis of variance of shoot/root ratio may indicate significant differences among treatments, the difference was related to the total size of the seedling. Larger seedlings had smaller shoot/root ratios regardless of treatment. The results of this study appear to agree with those observations. Seedlings under the $70 \%$ light, no stress treatment had the highest mean total weight $(.642 \mathrm{~g})$ and correspondingly lowest mean shoot/root ratio $(1.74)$.

\section{Dormancy Induction}

No differences in time of terminal bud set across all treatments were detected, and the terminal bud was visible on virtually all seedlings within 72 hours. Although buds in greenhouse grown western larch seedlings often rebreak these were the final resting buds of the season. This suggests that photoperiod was a more critical factor than light intensity or moisture stress for inducing a final resting bud and dormancy under the environmental conditions of this study. 
The importance of photoperiod in inducing the formation of resting buds and the onset of dormancy in European larch (Larix decidua Mi11.) is well known (Wareing 1969). Vaartaja (1959) found photoperiodic ecotypes in eastern larch (Laxix Zamicina (Du Roi) K. Koch) corresponded with latitude (critical daylength increased with latitude north), but Rehfeldt (1982) also noted genetic variation occurred in western larch with elevation (earlier bud set with higher elevation seed source). That the seed for this study originated from a single source (latitude and elevation), most likely contributed to the uniformity of bud set regardless of treatment.

Terminal buds first appeared on August 13 when daylength was approximately 14 hours. Vaartaja (1959) found that in 1-year-old eastern larch seedlings from as far south as $46^{\circ}$ latitude, critical daylength for terminal dormancy was also 14 hours.

\section{Water Relations}

Diurnal leaf conductance $\left(K_{1}\right)$ of unstressed and stressed seedlings measured August 4 are shown in Figure 4. The unstressed seedlings at that date responded poorly to ABHD (Table 2) compared to seedlings measured later. This may be attributable to immaturity of the terminal needles which had not developed stomatal mechanics, al though stomatal closure did occur when there was internal moisture stress. Richards (1980) detected a similar dampening of stomatal response in immature needles of alpine larch (Larix Zyazzii Parl.). The reduction in $k_{1}$ of the stressed seedlings (mean $B \Psi_{p}=-1.65 \mathrm{MPa}$ ) was similar to that of 
Figure 4. Diurnal measurements taken August 4, 1982 of photon flux density (PPFD), absolute humidity deficit (ABHD) and leaf conductance $\left(K_{1}\right)$ of unstressed $\left(B \Psi_{p}>-0.4 \mathrm{MPa}\right)$ and stressed seedlings ( $\left.B \Psi_{p}=12.5-20.0 \mathrm{MPa}\right)$. Stressed and unstressed seedlings denoted by $(0)$ and $(0)$ respectively. A11 points are means of 3 seedlings with one standard error indicated (bars). 


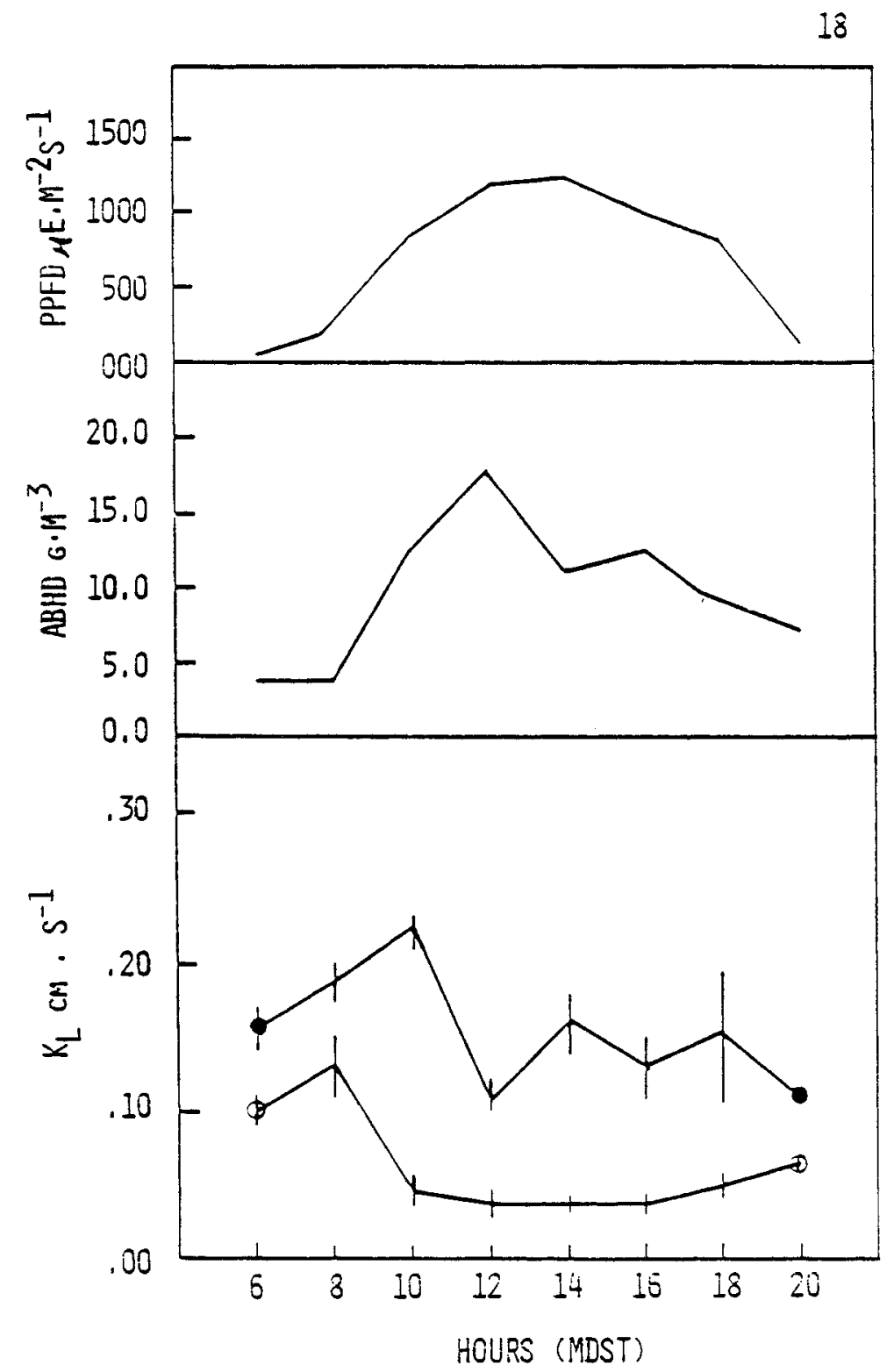


Table 2. Summary of regressions of leaf conductance with humidity deficit, predawn xylem water potential, and both independent variables entered stepwise.

\begin{tabular}{|c|c|c|c|c|}
\hline DATE & $\begin{array}{l}\text { SEEDLING } \\
\text { WATER STATUS }\end{array}$ & $\begin{array}{l}k \text { vs } \\
r^{2}\end{array}$ & $k \underset{r^{2}}{v s} B \Psi_{p}$ & $k$ vs $\underset{r^{2}}{B \Psi}$ \\
\hline \multirow[t]{2}{*}{ August 4} & Unstressed & .02 NS & .11 NS & $.38 \mathrm{NS}$ \\
\hline & Stressed & .01 NS & $.74 * \star *$ & $.75 * * *$ \\
\hline \multirow[t]{2}{*}{ August 16} & Unstressed & $.82 \star \star \star$ & $.01 \mathrm{NS}$ & 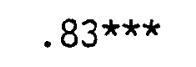 \\
\hline & Stressed & $.27 \star \star$ & $.15^{x}$ & $.75 * \star \star$ \\
\hline
\end{tabular}

Significance difference at the .001 level, $* * *$; significant difference at the .01 level, **; significant difference at the .05 level, *; no difference, NS. 
stressed seedlings (mean $B \Psi_{p}=-1.7 \mathrm{MPa}$ ) measured August 16 (Figure 5) and agreed with a comparable pattern described by Hinckley et al. (1978) and Davies et a1. (1981).

Diurnal $K_{1}$ patterns of the shaded and unshaded seedlings from the unstressed treatment measured August 16 are shown in Figure 5. Although maximum $k_{1}$ was not significantly different between the shaded and unshaded seedlings, $K_{1}$ was significantiy lower at high levels of ABHD. The greater decline in $k_{1}$ of the shaded seedlings having the same water status may have been due to stomatal response to reduced light intensity and was also noted by Havranek and Benecke (1978) and Kaufmann (1976). The decrease in $K_{1}$ which reduced transpirational water loss probably contributed to the difference in diurnal pattern of water potential $\left(\Psi_{p}\right)$ of shaded and unshaded seedlings measured August 16 (Figure 5). Shaded seedlings showed a significantly higher minimum $(-0.59 \mathrm{MPa})$ than the unshaded seedlings $(-0.85 \mathrm{MPa})$.

Diurnal measurements of $K_{1}$ and $A B H D$, and corresponding $B \Psi_{p}$ were further analyzed by regressing $K_{q}$ with $A B H D$ and $B \Psi_{p}$ individually, and $K_{1}$ with $A B H D$ and $B \Psi_{p}$ in a stepwise multiple regression. A summary of the results is shown in Table 2. Except for the unstressed seedlings measured August 4 , the relation between $K_{7}$ and $A B H D$ and $B \Psi_{p}$ is significant. The lack of significance in the August 4 unstressed seedlings is attributed to the variability in stomatal behavior of the immature terminal needles. The relationship between $B \Psi_{p}$ and $K_{7}$ has been shown by Running $(1976,1980)$. As $B \Psi_{p}$ decreased, or internal moisture stress 
Figure 5. Diurnal measurements taken August 16, 1982 of absolute humidity deficit (ABHD), seediing water potential ( $\Psi p$ ) and leaf conductance $\left(K_{l}\right)$ of unshaded $(O)$, shaded $(Q)$, and stressed $(O)$ seedlings. All points are means of 3 seedlings with one standard error indicated (bars). 


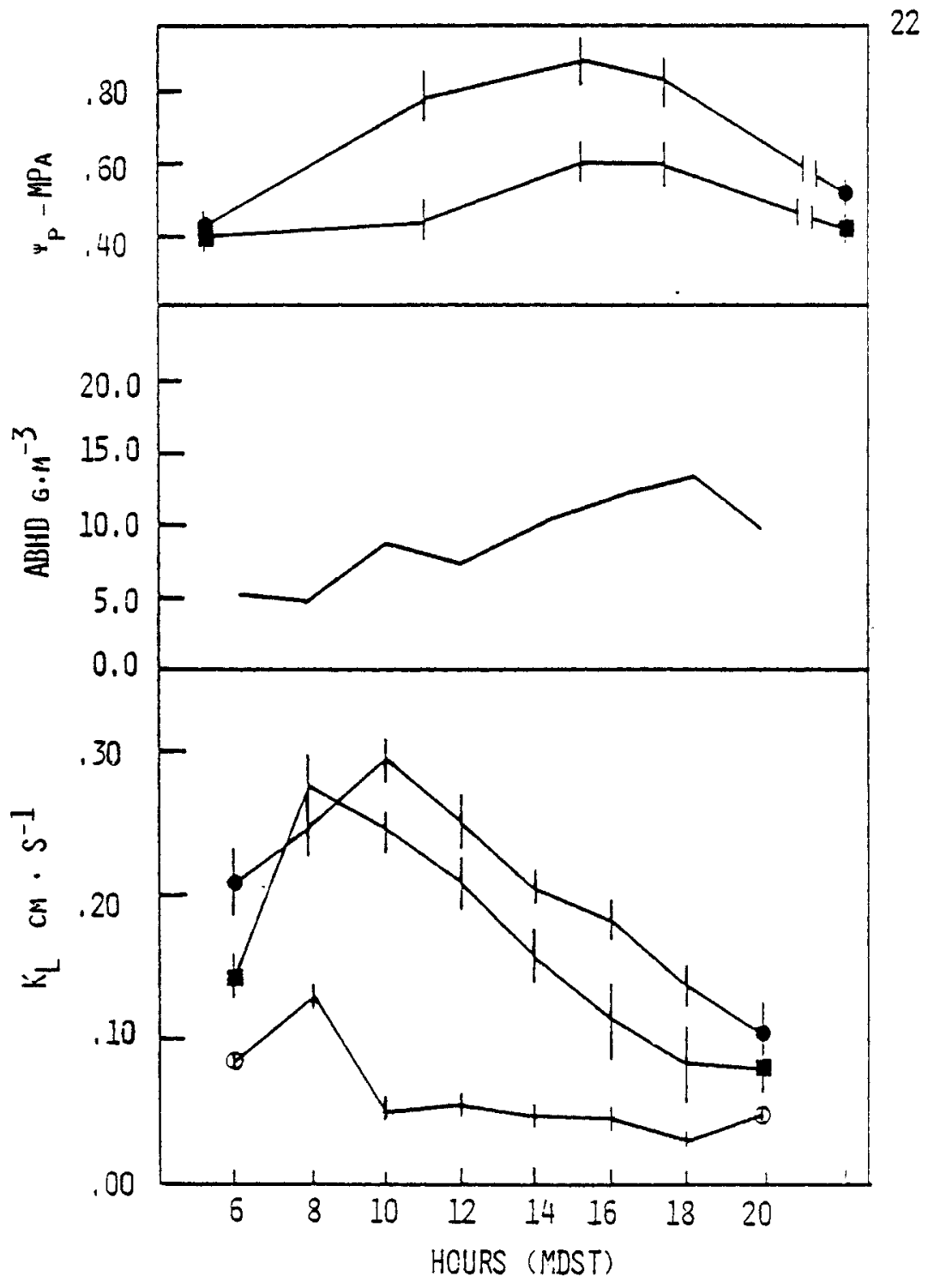


increased, its influence on $k_{1}$ correspondingly increased until at some critical level it overrode not only stomatal response to $A B H D$, but the photoactive response as wel1, which agrees with Hinckley et al. (1978).

The direct relationship of $B \Psi_{p}$ and maximum $K_{1}$ is demonstrated for western larch and lodgepole pine (Pinus contorta Dougl. ex Loud.) from Running (1980) in Figure 6. Although the fitted regression line indicated the response of western larch to declining $B \psi_{p}$ was similar to that of lodgepole pine, maximum $k_{1}$ did not decline as rapidly to increasing internal water stress. At even severe stress levels $(B \Psi=-2.0 \mathrm{MPa})$, levels of maximum $K_{1}\left(>.10 \mathrm{~cm} \cdot \mathrm{s}^{-1}\right)$ indicated stomata were still partially open. Seedings stressed to $B \Psi_{p}=-1.5 \mathrm{MPa}$ still opened stomata photoactively (Figures 4, 5 and 6) whereas lodgepole pine stomata did not (Figure 6) indicating less ability by western larch seedlings to conserve water under stress. This agrees with Havranek and Benecke (1978) who found that stomata of two-year-old eastern larch did not react as sensitively as lodgepole pine to declining $\Psi_{p}$.

The curves in Figure 7 resemble soil moisture tension release curves and suggest close coupling of $B \Psi_{p}$ to the water potential of the container soil. This assumes equilibrium conditions existed when $B \Psi_{p}$ was measured (Havranek and Benecke 1978, Hinckley et al. 1978). The second moisture stress cycle took several days longer to produce the same $B \Psi_{p}$ in comparable seedlings. There were no changes in the greenhouse environment over the time span of the stress cycles that could have accounted for 
Figure 6. A second degree regression from a least squares curve fit of maximum morning leaf conductance $\left(K_{1}\right)$ on predawn seedling water potential $\left(B \Psi_{p}\right)$. The solid line is from the equation fitting the data polnts for western larch. The dashed line is for lodgepole pine from Running (1980). 


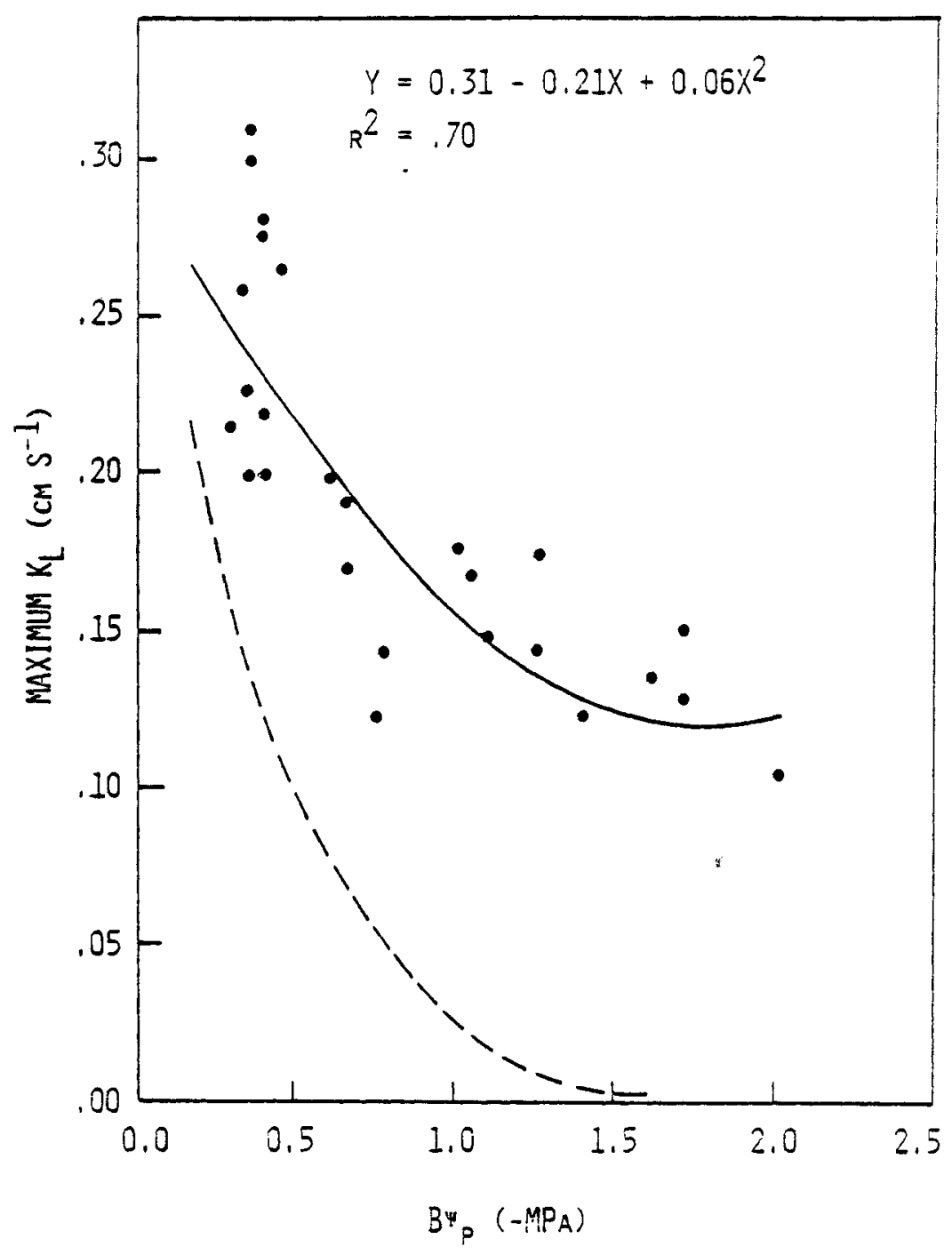


Figure 7. Seedling predawn xylem pressure potential $\left(B \Psi_{p}\right)$ during two consecutive stress cycles. Each point is the mean of 3 measurements taken of seedlings under $70 \%(0)$ and $27 \%$ (口) light treatments. The first stress cycle is denoted by $(-)$, the second cycle by $(--)$. 


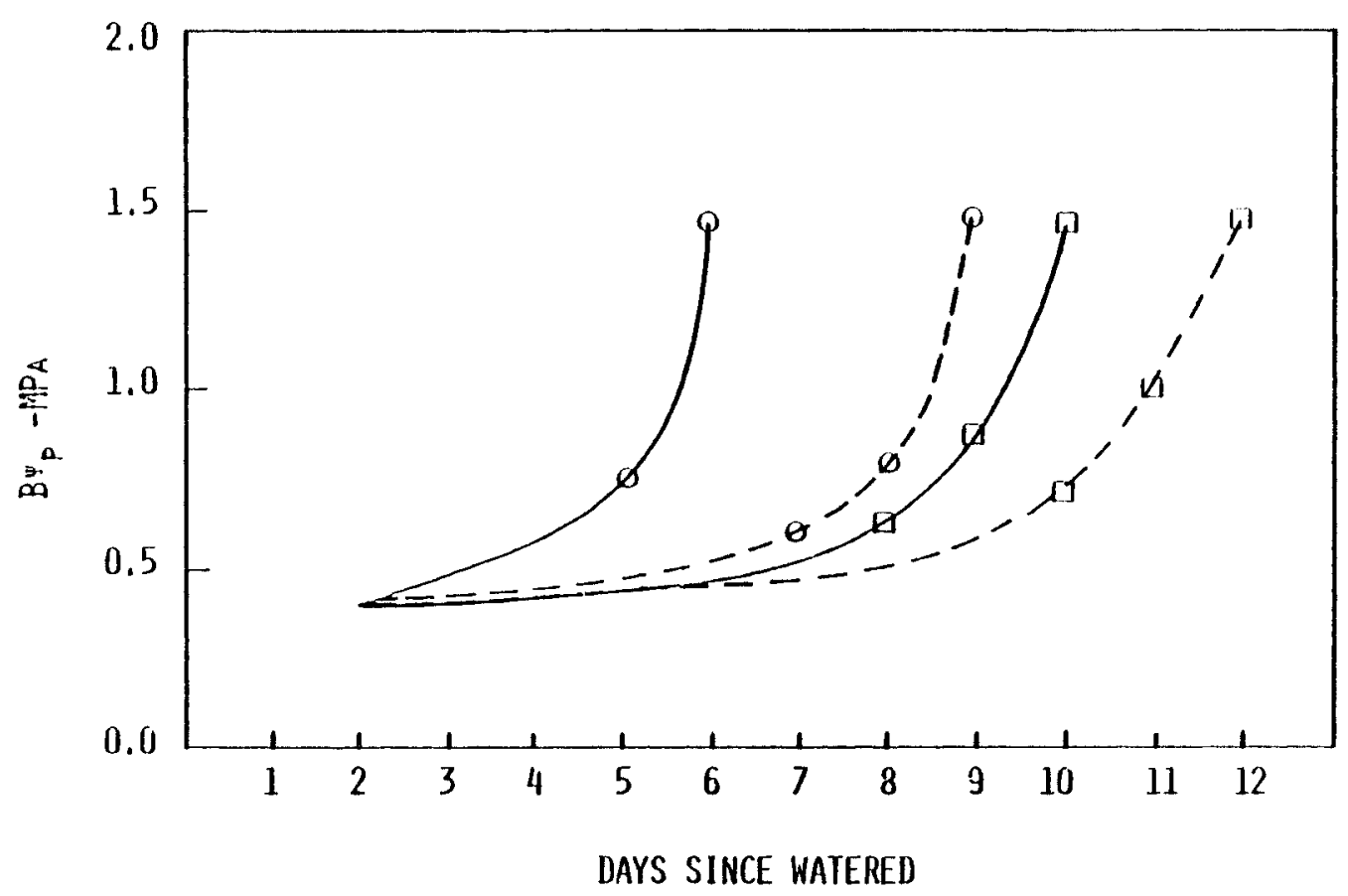


this. Changes in seedling stem and needle morphology over the stress cycling period could have possibly accounted for the apparent adaptation; however these and physiological adjustments were not quantified. In studies by Johnson and Ferrell (1982) and Newville and Ferrell (1979) seedlings were placed under 2 consecutive stress cycles, and al though the second cycle also took longer for seedlings to achieve the same $B \Psi_{p}$, the means of the apparent adaptation including greater stomatal control or osmotic adjustment were not ascertained.

\section{CONCLUSIONS}

Seedling height growth responded significantly to moisture stress and continued after bud set. The considerable variability in height suggests height growth is not very predictable with this species and less emphasis should be placed on it as an attribute of seedling quality. The direct relationship of root dry weight to light intensity and the dramatic increase in root dry weight late in the growing season under relatively high light suggests that as long as moisture is available shading larch after bud set is contraindicated. Although shoot dry weight also increased with increased light intensity, relatively more dry matter was allocated to the shoots than the roots with light reduction. In general, the highest light intensity produced the largest seedlings by weight with the lowest shoot/root ratios.

Bud set timing was not influenced by moisture stressing or light intensity reduction but by the 14 hour photoperiod. This suggests 
that while moisture stressing may induce a temporarily resting bud in larch, truly dormant buds could best be induced by photoperiod control.

Despite western larch seedlings' apparent fragility and relative needle succulence, water relations were generally characteristic of other conifers. Data indicated that stomatal closure occurred at a threshold level of $\Psi_{p}$; however, seedlings had a persistent photoactive response even under stressful conditions which resulted in less stomatal control in reducing transpirational water loss. Nevertheless, seedlings were able to recover from predawn moisture stress as great as $-1.5 \mathrm{MPa}$ and displayed an adjustment to stressing which could provide the seedling with a protective mechanism against subsequent episodes of moisture stress. 


\section{LITERATURE CITED}

Beardsell, M. F., P. G. Jarvis and B. Davidson. 1972. A null-balance diffusion porometer suitable for use with leaves of many shapes. J. Appl. Ecol. 9:677-690.

Cleary, B. D., R. D. Greaves, R. K. Hermann. 1978. Regenerating Oregon's Forests. Oregon State Ext. Serv. Corvallis, Ore. $286 \mathrm{p}$.

Davies, W. J., J. A. Wilson, R. E. Sharp and O. Osunubi. 1981. Control of stomatal behavior in water-stressed plants. Stomatal physiology (P. G. Jarvis and T. A. Mansfield, eds.) p. 163-186. Cambridge University Press. New York.

Drew, A. P. and S. W. Running. 1975. A comparison of two techniques for measuring surface area of conifer needles. For. Sci. $21: 231-232$.

Fairbairn, W. A. and S. A. Neustein. 1970. Study of response of certain coniferous species to light intensity. Forestry 57-71.

Havranek, W. M. and U. Benecke. 1978. The influence of soil moisture on water potential, transpiration and photosynthes is of winter seedlings. Plant and Soil 49, 91-103.

Hinckley, T. M., J. P. Lassoie and S. W. Running. 1978. Temporal and spatial variations in the water status of forest trees. Forest Science Monograph 20.

Hsiao, T. C., E. Acevedo, E. Fereres and D. W. Henderson. 1976. Water stress, growth and osmotic adjustment. Philes Trans R. Soc. Land 273:478-500.

Johnson, J. and W. K. Ferrel1. 1982. The relationship of abscisic acid metabolism to stomatal conductance in Douglas-fir during water stress. Physiol. Plant. 55:431-437.

Kaufmann, M. R. 1976. Stomatal response of Engelmann spruce to humidity, 1ight, and water stress. Plant Physiol. 57:898-901.

Kozlowski, T. T. 1971. Control of shoot growth 296-386. In: Growth and development of trees. Vol. 1. Academic Press. New York. 443 p. 
Larson, P. R. 1974. The upper limits of seedling growth. p. 62-84. In: Proc. North Am. Containerized For Tree Seedlings Symp. (R. W. Tinus, W. E. Stein, and W. E. Bahmer, Eds.). Great Plains Agric. Counc. Publ. 68.

Ledig, F. T., F. H. Bormann and K. F. Wenger. 1970. The distribution of dry matter growth between shoot and roots in loblolly pine. Bot. Gaz. 137(4):349-359.

and D. B. Botkin. 1974. Photosynthetic C02-uptake and the distribution of photosynthate related to growth of larch and sycamore progenies. Silvae Genetica. 188-192.

and T. 0. Perry. 1965. Physiological genetics of the shootroot ratio. pp. 39-43. In: Proc. Soc. Amer. Foresters 1960, Detroit, Michigan.

Levitt, J. 1980. Responses of Plants to Environmental Stresses. Vol. II Water, radiation, salt and other stresses. Academic Press, New York. 606 p.

Logan, K. T. 1966. Growth of tree seedlings as affected by light intensity. II Red pine, white pine, Jack pine and eastern larch. Dept. of For. Pub1. \#1160. Ottowa, CA. 19 p.

Newville, E. G. and W. K. Ferrell. 1980. Abscisic acid levels and stomatal behavior during drought and recovery in Douglas-fir (Pseudotsuga menziesii) Can. J. Bot. 58:1370-1375.

Owens, J. W. and M. Molder. 1979. Bud development in Larix occidentalis. I. Growth and development of vegetative long shoot and vegetative short shoot buds. Can. J. Bot. 57:678-700.

Rehfeldt, G. D. 1982. Differentiation of Laxix occidentalis populations from the Northern Rocky Mountains. Silvae Genetica 31:1 13-19.

Richards, J. H. 1981. Ecophysiology of a deciduous timberline tree, Lamix ZyalZii Parl. Ph.D. dissertation. U. of Alberta. Edmonton, Alberta.

Ritchie, G. A. and T. M. Hinckley. 1975. The pressure chamber as an instrument for ecological research. Adv. Ecol. Res. 9:165-254.

Running, S. W. 1976. Environmental control of leaf water conductance in conifers. Can. J. For. Res. 6:104-1112.

1980. Environmental and physiological control of water flux through Pinus contorta. Can. J. For. Res. 10:82-91. 
Schmidt, W. C., R. C. Shearer, A. L. Roe. 1976. Ecology and Silviculture of western larch forests. U.S. Dep. Agric., Tech. Bull. $1520,96 \mathrm{p}$.

Shiroya, T., G. R. Lister, V. Slankis, G. Krotkov, and C. D. Nelson. 1962. Translocation of the products of photosynthes is to root of pine seedlings. Can. J. Bot. 40:1125-1135.

Tinus, R. W. and S. E. McDonald. 1979. How to grow tree seedlings in containers in greenhouses. USDA For. Serv. R.M. For. and Range Exp. Sta. Fort Collins, Co. Gen. Tech. Rep. RM-60. 256 p.

Tranquillini, W. 1979. Physiological ecology of the alpine timberline. Springer-Verlag. Berlin, Heidelberg, New York.

Vaartaja, 0. 1959. Evidence of photoperiodic ecotypes in trees. Ecological monographs $29: 91-111$.

Wareing, P. F. 1969. Germination and dormancy. pp. 606-609. In: Physiology of Plant Growth and Development in B. Wilkins (ed.). McGraw-Hill. England. 